\title{
An Experimental Behavior of Chemical Cement and Properties of Chemical Components
}

\author{
Prof. Barry Wiling \\ Professor, Department of Computer Science, \\ U.S.M.N Oman \\ barrywiling@usmn.edu
}

\section{Abstract}

As we understand that solid a famous confining material. It is an imperative assistant structure material. Rough materials for solid creation are limestone, sand or mud, bauxite, and iron mineral, and may join sheets, chalk, marl, shale, earth moreover influence sway warmer slag. Mixture assessment of solid unrefined materials gave data into the substance properties of cement.

Keywords: Silica, Lime, fineness etc.

\section{INTRODUCTION}

Concrete is a coupling material utilized in the headway business. Concrete consistently recommends an exceptionally fine substance by and large contained limestone, sand or earth, bauxite, and iron metal, and may combine shells, chalk, marl, shale, mud, influence radiator slag, record. It sets all around brought down and sets rapidly and accomplishes quality. Solid complexities from lime by the property that it doesn't slake at any rate set quickly. It has water driven properties, so to speak, and gets more noteworthy quality in the setting. The setting force of cement is more than that of lime. Believe it or not, It is a calcareous substance that is utilized in mortar or cement for advancement.

\section{PHYSICAL PROPERTIES OF CEMENT}

\section{Soundness}

The unsoundness of cement is cause by the unfortunate extension of a portion of its constituents, once in a while in the wake of setting. The huge change in volume going with development brings about breaking down and serious splitting. The unsoundness is because of the presence of available time and magnesia in the cement. 
The unsoundness may diminish by

- $\quad$ Limiting the $\mathrm{MgO}$ substance to under $0.5 \%$.

- Fine grinding.

- Allowing the cement to circulate air through for a few days.

- Through blending.

\section{Compressive Strength}

It is one of the significant properties of cement. The quality test isn't made on slick cement paste on account of troubles in getting great examples and in testing with an ensuing enormous fluctuation of test outcomes. Cement-sand mortar or cement of recommended properties made with indicated materials under strictly controlled conditions stirred to decide the quality of cement.

\section{Standard Consistency Test of Cement}

Consistency alludes to the capacity to stream of a newly blended cement glue or mortar. Standard consistency some of the time is called typical consistency. This test gives the thought regarding the prerequisite of water substance to create a cement paste in a legitimate way, neither wet nor dry. At the end of the day, it gives the base amount of water required to start the substance response among water and cement content. The measure of water assumes a huge job in cement glue/solid/mortar. It's an experimentation type analyze led in the research facility.

\section{CHEMICAL PROPERTIES OF CEMENT}

Dicalcium silicate -Dicalcium silicate (C2S) hydrates and hardens and hardens gradually and gives a significant part of a definitive quality.

Magnesis (MgO) -The assembling procedure of Portland cement utilizes magnesia as a raw material in dry procedure plants.

Sulfur Trioxide -Sulfur trioxide in excess sum can make cement unsound.

Ferric oxide -Beside including quality and hardness, iron oxide or ferric oxide is fundamentally liable for the color of the cement.

Alkalis- The measure of potassium oxide $\mathrm{K} 2 \mathrm{O}$ and sodium oxide $\mathrm{Na} 2 \mathrm{O}$ decide the alkali base substance of the cement.

Alumina- Cement containing high alumina can withstand bone chilling temperatures since alumina is compound safe. 


\section{TABLE 1:}

\section{CHEMICAL PROPERTIES OF CEMENT}

\begin{tabular}{|l|l|l|}
\hline S. No. & Name & Composition (\%) \\
\hline 1 & Lime & $63.72 \%$ \\
\hline 2 & Silica & $32.39 \%$ \\
\hline 3 & Magnesia(MgO) & $2.02 \%$ \\
\hline 4 & Sulphur trioxide & $3.17 \%$ \\
\hline 5 & Ferric oxide & $6.89 \%$ \\
\hline 6 & Alkalis & $1.0 \%$ \\
\hline 7 & Loss on ignition & $2.82 \%$ \\
\hline 8 & Alumina & $5 \%$ \\
\hline
\end{tabular}

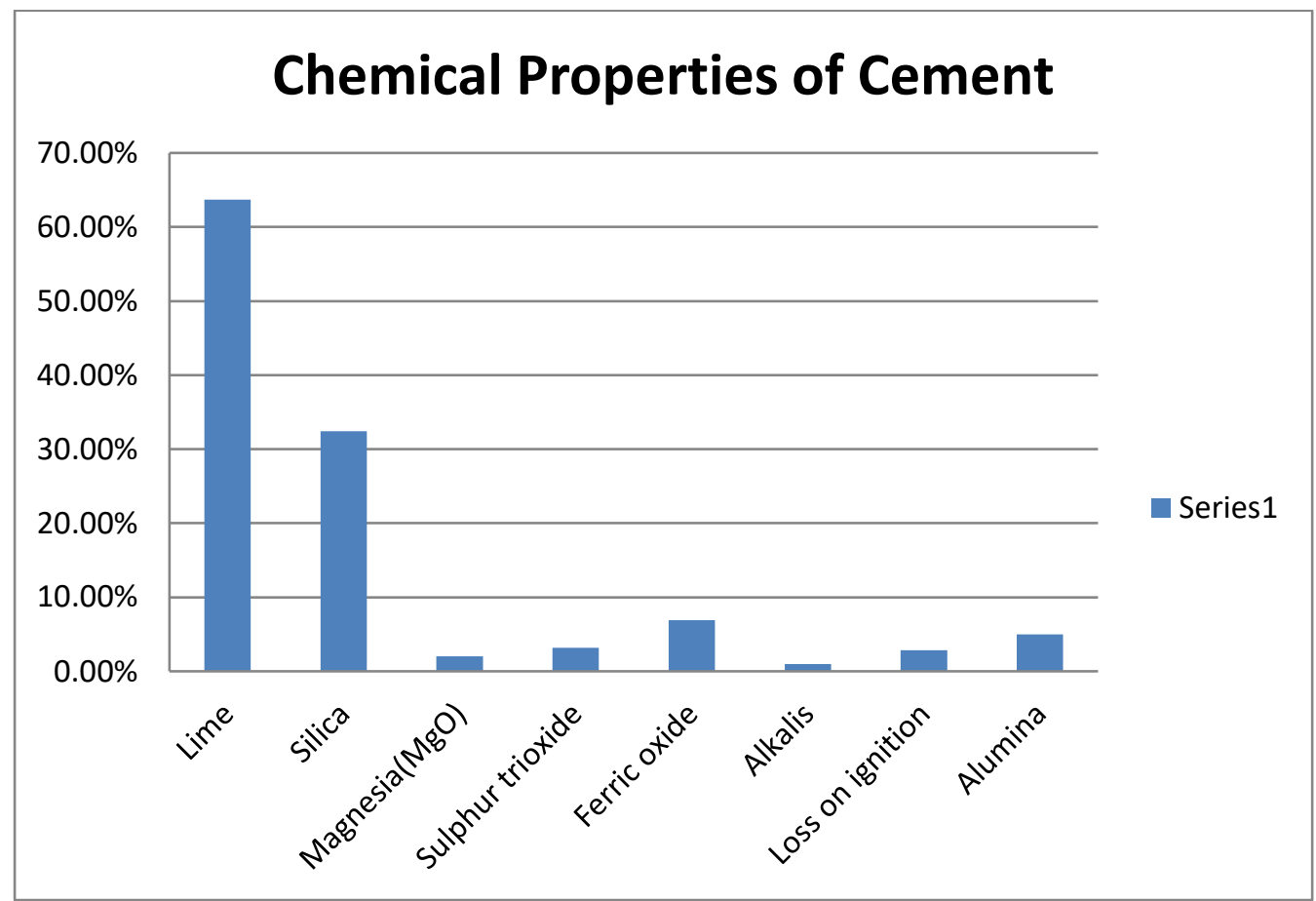

\section{EFFECT OF VARIATIONS IN CHEMICAL COMPONENTS:}

- $\mathrm{MgO}$ (Magnesia): The excess amount of $\mathrm{MgO}$ leads todetrimental development. This extension happens because of the hydration of free $\mathrm{MgO}$ in solidified cement. $\mathrm{MgO}$ ought to be restricted to $4 \%$.

- Free CaO: Free Cao gives a similar impact as $\mathrm{MgO}$. Free Cao shows an enormous volume extension after hydration which prompts the breaking down of solidified cement. 
- $\mathrm{Na} 2 \mathrm{O}$ and $\mathrm{K} 2 \mathrm{O}$ (Salt Oxides): The excess amount of alkalis gives alkali-aggregate reaction which brings about troublesome extension.

\section{CONCLUSION}

Cement contains various ingredients as its raw material like lime, silica, alumina, iron oxide and so on. These ingredients interface with each other in the kiln during the manufacturing procedure and make a mind boggling compound. Chemical properties have a significant impact either valuable or adverse on the quality of cement. It relies upon their limiting value in cement.

\section{REFERENCES}

[1] C. M. Hanson, "Concrete: the advanced industrial material of the 21 st century," Metallurgical \& Materials Transactions A, vol. 26, pp. 1321-1341, 1995.

[2] M. Bediako, S. K. Y. Gawu, and A. A. Adjaottor, "Suitability of some Ghanaian mineral admixtures for masonry mortar formulation," Construction and Building Materials, vol. 29, pp.667-671, 2012.

[3] S. H. Kosmatka, B. Kerkhoff, and W. C. Panarese, Design and Control of Concrete Mixtures, Portland Cement Association,Skokie, Ill, USA, 14th edition, 2002.

[4] M. S. Mamlouk and J. P. Zaniewski, Materials for Civil andConstruction Engineers, Prentice Hall, Upper Saddle River, NJ,USA, 2006.

[5] T. Punmatharith, M. Rachakornkij, A. Imyim, and M.Wecharatana, "Co-processing of grinding sludge as alternative raw material in portland cement clinker production," Journal of Applied Sciences, vol. 10, no. 15, pp. 1525-1535, 2010.

[6] D. N. Huntzinger and T. D. Eatmon, "A life-cycle assessment of Portland cement manufacturing: comparing the traditional process with alternative technologies," Journal of Cleaner Production, vol. 17, no. 7, pp. 668-675, 2009.

[7] F. M. Lea, The Chemistry of Cement and Concrete, Arnold Publishers, London, UK, 3rd edition, 1970.

[8] J. F. Young, S.Mindess, R. J. Gray, andA. Bentur,TheScience andTechnology of Civil Engineering Materials, Prentice-Hall, Upper Saddle River, NJ, USA, 1998.

[9] H. F. W. Taylor, Cement Chemistry, Thomas Telford, London,UK, 2nd edition, 1997.

[10] S. H. Kosmatka and M. L. Wilson, Design and Control of Concrete Mixtures, Portland Cement Association, Stokie, Ill, USA, 2011.

[11] V. Sata, C. Jaturapitakkul, and K. Kiattikomol, "Influence of pozzolan from various by-product materials on mechanical properties of high-strength concrete," Construction and BuildingMaterials, vol. 21, no. 7, pp. 1589-1598, 2007.

[12] A. Neville, Neville on Concrete, ACI, Farmington Hills, Mich, USA, 2003.

[13] R. Fernandez, F. Martirena, and K. L. Scrivener, "The origin of the pozzolanic activity of calcined clay minerals: a comparison between kaolinite, illite and montmorillonite," Cement and Concrete Research, vol. 41, no. 1, pp. 113-122, 2011.

[14] K. Ganesan, K. Rajagopal, and K. Thangavel, "Evaluation of bagasse ash as supplementary cementitious material," Cement and Concrete Composites, vol. 29, no. 6, pp. 515-524, 2007.

[15] S. Sinthaworn and P. Nimityongskul, "Quick monitoring of pozzolanic reactivity of waste ashes," Waste Management, vol.29, no. 5, pp. 1526-1531, 2009.

[16] J. J. Brooks,M. A.M. Johari, andM.Mazloom, "Effect of admixtures on the setting times of highstrength concrete," Cement and Concrete Composites, vol. 22, no. 4, pp. 293-301, 2000. 
Issue: November-December 2018 | Pages: 01 - 05

[17] X. Fu, Z.Wang,W. Tao et al., "Studies on blended cement with a large amount of fly ash," Cement and Concrete Research, vol. 32,no. 7, pp. 1153-1159, 2002.

[18] E.-H. Kadri, S. Kenai, K. Ezziane, R. Siddique, and G. De Schutter, "Influence of metakaolin and silica fume on the heat of hydration and compressive strength development of mortar," Applied Clay Science, vol. 53, no. 4, pp. 704-708, 2011.

[19] V. Indrawati and A. Manaf, "Mechanical strength of trass as supplementary cementing material," Journal of Physical Science, vol. 92, no. 2, pp. 51-59, 2008. 